\title{
ПОТРЕБА ОД БЕНЕФИЦИРАН РАБОТЕН СТАЖ ЗА ВРАБОТЕНИТЕ ВО ВОНИНСТИТУЦИОНАЛНА И ВО ИНСТИТУЦИОНАЛНА ЗАШТИТА ЗА ДЕЦА СО УМЕРЕНА И СО ТЕШКА ИНТЕЛЕКТУАЛНА ПОПРЕЧЕНОСТ
}

\section{Кратика сооржина}

Сисйемой на зашйийа и рехабилитиачија на лица со инвалионосй, како и восииитино-образовниой сисиеем во Рейублика Макеяонија оя 2000 іояина, йа gо оенес иррейрйе низа иромени ирреоизикани оя йрочесийе на gеинсииитучионализачија и инклузија. Ваквитие ирромени ирреоизвкуваай значитиелно яа се намали бројой на яеча со умерена иниелекитуална йойреченосй во яневните ченитри и во Завояой за рехабилиитачија на яеца и млаяинци ,Тойанско Поле“, а за смейка на ваквайа ииромена gа ооминираай яечайа со йешка инйелекииуална йойреченосй.

Менувањейо на ситрукӣурайа на корисницийе, зіолемувањейо на рабойниой ситаж на ситручнитете лича кои рабойай со оваа кайеторија яеца и слабайа наяворешна мойивираносӣ ӣреоизвкуваай йрофесионално соіорување.

Истиражувањет̄о е сировеоено на ирримерок оя 16 стиручни лича врабойени во Завояой за рехабилийачија на яеча и млаяинци „Тойанско Поле“ во Скойје и 94 сииручни лича врабойени во ченйрийе за яневно зірижување во Рейублка Макеоонија.

Каяарой шйо е аніажиран на йрейман на лича со йешка инйелекйуална иооиреченосй во Сйечијалниой завоя во Демир Кайија има рабойен сйаж кој се сметиа со зіолемено итраење. Зайоа исиражувањейо е сиировеяено со чел gа исйитиаме оали ситручнитие лица кои ја йокриваай оваа кайеіорија оеча имаай иолиреба оя яойолнииелно мойивирање и сииимулирање, како и вовеяување бенефициран рабойен стиаж како можносй за зіолемување на ефикасностиа во рабойењет̄о и йояобрување на квалитетиой на живой на ситручнитие йрофили кои се во оирекитен и секојяневен конйакй со яеца со умерена и со йешка инйелекйуална йойреченосй.

Клучни зборови: ДЕЦА СО УМЕРЕНА И ТЕШКА ИНТЕЛЕКТУАЛНА ПОПРЕЧЕНОСТ, ИНСТИТУЦИОНАЛНА И ВОНИНСТИТУЦИОНАЛНА ЗАШТИТА, ПРОФЕСИОНАЛНО СОГОРУВАҢЕ, БЕНЕФИЦИРАН РАБОТЕН СТАЖ 


\section{Вовеg}

Законот за работни односи на Република Македонија од 1993-1997 година укажува дека работниците кои работат на особено тешки, напорни и работни обврски што се тешки за нивното здравје може да имаат скратено работно време. Во овој Закон, меѓу другото, се потенцира дека тука спаѓаат и лицата кои работат со корисници со најтешка интелектуална попреченост. Законот за пензиско и инвалидско осигурување од 2000 година дополнува дека работниот стаж на наведената група работници може да се смета со зголемено траење (Мијалков Б., Петров Р., 2012).

Од 2000 година оваа област ја регулира Законот за пензиско и инвалидско осигурување. На работниците кои работат на особено тешки и штетни работни места за здравјето, како и на оние што работат на работни места на кои по одреден број надминати години од животот повеќе не можат успешно да ја извршуваат својата дејност, стажот на осигурувањето им се смета со зголемено траење.

Управниот одбор на Фондот за пензиско и инвалидско осигурување на Република Македонија, во постапка по член 127 од Закон за пензиско и инвалидско осигурување, ги утврдува во член 1 работните места во Специјалниот завод во Демир Капија на кои стажот им се пресметува со зголемено траење, и тоа: лекар 12/15 месеци, медицинска сестра 12/15, негувателка $12 / 16$, хигиеничарка $12 / 15$, работници во перална $12 / 14$, дефектолог $12 / 15$, работен инструктор $12 / 15$, воспитувач $12 / 15$, социјален работник $12 / 15$ и физиотерапевт 12/15 месеци.

Вклучувањето на категоријата работници кои работат директно со оваа популација луѓe се должеше на анализа направена во 2000 година со процена на однесувањето на вработените со работен стаж подолг од 15 години. Проценувано е дали работници имаат повисок степен на општа невротичност, изразено присуство на одредени невротски тенденции, поголема одбранбена насоченост и примена на примитивни механизми на одбрана, како и поизразено емотивно реагирање, субјективни тегоби и заболувања, во споредба со работници со пократок работен стаж од 15 години и вработени во основно училиште во Демир Капија (Мијалков Б., Петров Р., 2012).

\section{Мейооолоіија на истиражување}

Во рамките на квалитативниот приод е употребена методолошка постапка фокусни групи. Фокусните групи се спроведени со вработените во сите дневни центри во Република Македонија кои опфаќаат деца со умерени и со тешки пречки во интелектуалниот развој, како и во Заводот за рехабилитација на деца и младинци во Скопје.

Со започнувањето на процесот за деинституционализација, приемот на нови корисници во Специјалниот завод во Демир Капија е забранет, единствено е можен со 
дозвола издадена од министерот за труд и социјална политика во исклучителни ситуации кога лицата не можат да останат во семејни услови или се опфатени со друг вид третман. Со ваквата ситуација, бројот на деца до 18-годишна возраст во оваа институција е исклучително мал и се работи за деца со тешки или длабоки пречки во интелектуалниот развој. Од оваа причина, Специјалниот завод од Демир Капија не беше вклучен во истражувањето.

Примерокот на истражување го сочинуваа 16 испитаници од Заводот за рехабилитација на деца и младинци во Скопје и 94 испитаници од центрите за дневно згрижување кои работат како единици на центрите за социјална работа и згрижуваат деца со умерена и со тешка интелектуална попреченост.

Процентот на женски испитаници е поголем (80,9\%), а на машки помал $(19,1 \%)$.

Во зависност од работното место на кое работат испитуваните лица, 22,7\% се дефектолози, $17,3 \%$ се социјални работници, $10 \%$ се психолози, а 44,5\% не се ниту еден од овие наведени кадри. Во четвртата група се вработени кои се педагози, социолози, технички персонал, а во мал дел и логопеди и физиотерапевти. Последната група е хетерогена во поглед на висината на образованието, но во најголем дел се со ниско или со средно образование. Во однос на работниот статус, во најголемиот процент - 92,7\% се вработени на неопределено време. Речиси половината од испитаниците - 52,7\% имаат работен стаж од 6 до 15 години, а 40,9\% повеќе од 15 години.

Примерокот на стручни лица вработени во вонинституционална заштита и на терен е евидентно поголем, но, за жал, дел од вработените во институционалната заштита не ни излегоа во пресрет и немаа желба да разговараат за нивната работа. Низ разговор со некои од вработените, добивме слика дека незаинтересираноста се должи на неизвесноста што ја има кај вработените по сите промени во социјалната сфера, но и поради сѐ полошата структура на деца со кои работат. Во исто време, најголем дел од вработените во оваа институција имаат подолг работен стаж и ваквата несоработка може да ја припишеме на професионалниот стрес и професионалното согорување.

Неизвесноста од судбината на институцијата беше присутна и кај вработените во Специјалниот завод во Демир Капија пред започнувањето на процесот на деинституционализација, но ваквата неизвесност се провлекуваше и со години потоа. Незадоволството доминираше со започнување на процесот на деинституционализација, што се покажа како неосновано. Истражување направено во оваа институција покажува дека речиси половината од испитаниците, или 47,14\%, велат дека се плашат за својата иднина. Од овој процент, 29,26\% отпаѓаат на негувателките, но и на дефектолозите и повеќето од стручниот тим ја искажале својата загриженост. Заслужуваше внимание, но и загрижуваше, фактот што $34,15 \%$ од негувателките, односно $42,85 \%$ од дефектолозите и од воспитувачите, јасно кажуваат дека воопшто не го прифаќаат процесот.

И испитаниците од Специјалниот завод во Демир Капија, но и испитаниците од оваа истражување како главни проблеми ги истакнуваат големиот број корисници на еден вработен, немањето доволно средства за работа, зголемената бучавост на работното место, 
силната миризба, бројни инфекции поради недоволната грижа за децата во домашни услови, но и тоа дека медицински не се покриени доволно и во институциите во кои се упатени на третман. Зголемена телесна тежина кај оваа категорија деца поради нивната слаба подвижност и интелектуалната попреченост најчесто придружена со моторни нарушувања, но и неможноста за контрола на исхраната е дополнителна тешкотија за вработените, а тоа подразбира да бидат и физички јаки. Менталното и физичкото вложување велат дека се одразува и на нивната здравствена состојба и на нивното функционирање во нивните семејни услови. Постојаното кревање тешки корисници и вревата што ја создаваат, лошите хигиенски услови, се причини за кои сметаат дека доведуваат до здравствени проблеми и лошо расположение.

Законот за работни односи на Република Македонија, донесен во 1993 година и неговите измени во 1994, 1995 и во 1997 година, во член 32 вели: „На работникот кој работи на особено тешки, напорни и штетни работи за здравјето, а чие штетно влијание на неговото здравје, односно работна способност не може во целост да се отстрани со заштитни мерки, работното време му се скратува сразмерно на штетното влијание врз неговото здравје, односно работната способност...

Како особено тешки, напорни и штетни работи за здравјето се сметаат: ...работа со лица со најтешки пречки во психичкиот развиток...“1

Работата со лица со интелектуална попреченост бара од вработените максимална толерантност, потполно разбирање, воздржаност, самоконтрола. Таквата работа може успешно да ја извршува само психички здрава и емоционално стабилна личност која е во состојба да ги контролира своите емоции, т.е. емоционално соодветно да реагира во дадени ситуации и да ги инхибира нагонските пунзии што се косат со општествените норми. Тоа значи дека таквата личност нема да се возбуди поради мали ситници, но во сериозни ситуации нема да остане рамнодушна. Таквата личност се карактеризира со постојаност и истрајност во работата и со способност за борба со животните тешкотии, како и способност да се издржат евентуалните неуспеси во животот. Зрелата личност е толерантна и ја цени толерантноста на другите луѓе, ги прифаќа луѓето такви какви што се, во состојба е внимателно да се сконцентрира повеќе на проблемите околу себе. Спонтана е во акциите, независна, самостојна, со развиени социјални чувства и симпатии кон луѓето и со развиени етички принципи (Петров, Р., 2012).

За групата испитаници кои се вработени во институционалната заштита е интересно што покажуваат највисока способност за заземање туѓо гледиште. Ваквите резултати веројатно се должат на долгиот работен стаж на испитаниците од институционалната заштита, но и на фактот дека вработените во Заводот за рехабилитација на деца и младинци поминуваат подолго време со своите корисници. Со оглед на тоа што оваа институција останува отворена и за време на викендите и празниците, нејзините вработени имаат почести контакти со корисниците и по завршувањето на конкретните активности што се однесуваат директно на третманот. И дежурствата и ноќните смени придонесуваат вработените во институционалната заштита да се соочуваат со најразлични проблеми на децата и да ја имаат способноста да сочувствуваат со нив. Овие испитаници и

\footnotetext{
' Закон за пензиско и инвалидско осигурување, Сл. весник на РМ, бр. 80/93, 3/94, 14/95, 32/97 и 24/2000
} 
самите велат дека пред да заземат личен став, најчесто се обидуваат да се стават во ситуација на детето или на неговото семејство.

На примерок од 33 случајно избрани вработени од Заводот за воспитание и образование „Винко Бек“ во Нов Град во Хрватска во 2009 година, спроведено е истражување со цел да се утврди мотивацијата и задоволството од работата. Истражувањето ни покажува дека главен мотиватор претставуваат парите, потоа должината на годишниот одмор и работното време.

Со истражувањето под работен наслов „Кон барањата за утврдување на работните места на кои стажот на осигурувањето се смета со зголемено траење во Специјалниот завод во Демир Капија“, изработено во ЈУ Специјален завод во Демир Капија од Медицина на труд, Здравствен дом - Скопје, направена е споредба на две групи вработени во Специјалниот завод во Демир Капија, од кои првата група ја сочинуваат 47 вработени чии работни задачи се во директен контакт со корисниците (негуватели, дефектолози, воспитувачи, социјални работници и медицински персонал) со стаж на експозиција над 15 години и просечна возраст од 47,8 години и втора група составена од 16 вработени соодветна на првата по стручност и работни задачи, но со разлика што нивниот стаж на експозиција е до 15 години и просечна возраст од 30,6 години. Како контролна група се земени 29 вработени од основно училиште од Демир Капија, со просечен работен стаж од 19,7 години и просечна возраст од 43,9 години. Резултатите од проектот јасно ги одразуваат психолошките проблеми со кои се соочуваат вработените со работно искуство над 15 години со лица со длабока интелектуална попреченост. Високиот процент на изразеност на анксиозност, фобичност, кардиоваскуларно и хипохондриска тенденција (над 50\%) укажуваат на дијагностички невротски промени кај вработените од првата група, кои се манифестираат со чувство на страв, напнатост, вознемиреност, склоност кон соматизација. Процентуалната изразеност на општата невротичност кај вработените изнесува 41,9\%, што се приближува кон границата на висока невротичност. Резултатите од тестот „Животен стил“ покажуваат дека вработените од првата група имаат статистички значајно повисока општа одбранбена насоченост и почесто користат регресија, преместување, проекција и интелектуализација како механизми на одбрана во однос на другите две групи. Високата општа одбранбена насоченост упатува на повисок степен на анксиозност и пониско самопочитување кај вработените од првата група. Резултатите од тестот „Индекс на профил на емоции“ покажуваат дека изложеноста на хроничен професионален стрес води до промени на емоционалната состојба, што од своја страна ги менува цртите на личноста. Поизразеното присуство на потиштеност и автоагресивност како црти на личноста кај испитаниците од првата група во однос на другите две групи упатува од зголемен ризик од психосоматски заболувања. Од друга страна, присуството на цртите недоверба и склоност кон препирање имаат негативно влијание на интерперсоналните контакти. Изложеноста на хроничен професионален стрес кај вработените придонесува за почести заболувања од кардиоваскуларни и локомоторни болести и почесто како на субјективни соматски тегоби (главоболка, стенокардија...), така и на субјективни психички тегоби (напнатост, нервоза и 
замор) што води до почеста употреба на седативи. Резултатите се потврда дека работата со длабоко ментално ретардирани лица претставува своевиден психосоцијален стрес кој остава последици врз здравјето на вработените. Покрај тоа, овие резултати се поддршка за тврдењето дека менталните и кардиоваскуларните болести, кои се две главни групи болести поврзани со работата, во значителна мера се поврзани со физичките и психосоцијалните штетности на работата со посредство на хроничниот професионален стрес. Сите опишани промени, како и менталната и соматската состојба, ја нарушуваат емоционалната стабилност на вработените, што значи свртеност на вниманието кон себе и субјективни тегоби, намалена толеранција и неспособност да се прифатат луѓето такви какви што се, што води до конфликти со околината, намален интерес за социјални активности, несигурност и намалена истрајност во работата - што во голема мера ја намалува ефикасноста и успешноста во извршувањето на работните задачи.

Податоците укажуваат дека вработените во институционална заштита имаат помала мотивација за работа. Ваквата немотивираност, велат, дека се должи на неизвесната ситуација во која со години се наоѓa нивната институција. Промената на структурата на корисниците и примањето корисници со понизок степен на интелигенција и во голем број со дополнителни секундарни проблеми придонесува да имаат помала мотивација за работа. Исто така, и намалувањето на бројот на нови корисници придонесува за преиспитување на можностите за преструктурирање на институцијата. Вработените со подолг стаж и во двете групи гласно укажуваат на професионалното согорување, со оглед на структурата на корисниците и нивната ангажираност на сите работни операции, без оглед на профилот.

Во вонинституционална заштита се среќаваат стручни лица со статус на волонтери. Самото тоа што е присутна кај волонтерите неизвесноста за нивно понатамошно ангажирање, очекувавме дека тие ќе покажат помал интерес за работа, но, спротивно на тоа, тие немаат отстапувања и имаат внатрешна мотивација. Самите велат дека се подготвени да работат сѐ, само да бидат примени во редовен работен однос. И другите вработени укажуваат дека и покрај тоа што не ги обврзува установениот работен однос, беспрекорно ги извршуваат сите работни обврски. Од друга страна, за вработените во редовен работен однос претпоставувавме дека со самото тоа што редовниот работен однос сам по себе носи обврски, ќе бидат поисполнителни на работното место. И редовниот паричен надомест сметавме дека ќе претставува дополнителен мотив за работа на стручните лица.

Сите вработени укажуваат дека имаат мало или немаат никакво познавање за работа со деца со аутизам и аутистичен спектар на нарушувања кои се сѐ позачестени во сите дневни центри и во Заводот. Сите сметаат дека обуки од типот Сензорна интеграција и ABBA, TЕАСН и слични методи би им биле од голема корист. Испитаниците ја истакнуваат и потребата од вклучување покреативни техники во работата (музико-терапија, арттерапија, игра на улоги, асистивна технологија) како неопходност во нивното континуирано професионално надградување. Ова се должи сигурно на тоа што обуките воопшто не се поврзани со работа со деца со умерена и со тешка интелектуална попреченост и особено со методи и техники за работа со овие деца. 
Едно од прашањата на кое вработените одговараа во рамки на фокус-групите беше: Какво е професионалното задоволство на вработените во дневните центри? Речиси без исклучок, сите вработени одговараа дека ја сакаат својата работа, а повеќе од половината и дека премногу ја сакаат. Овој податок би требало да биде премногу охрабрувачки, бидејќ и покажува дека вработените не ги поколебуваат тешкотиите со кои тие се соочуваат на работа, но и дека посветеноста на работата дава гаранција дека во доволна мера ќе се ангажираат во решавање на проблемите што ќе се појават. Меѓутоа, повеќе од половина од кадарот би ја променил сопствената работа, и тоа, пред сѐ, поради лошиот статус во општетсвото и малите плати, како и неможноста за напредување во сопствената професија.

Во однос на прашањето поврзано со професионалното согорување на работното место, најголем број од вработените сметаат дека феноменот на согорување настанува кај вработените кои работат директно со штитениците над 15 години, додека еден помал дел сметаат дека може да се јави и две-три години по директната работа со децата, а други, пак, негираат дека во рамките на оваа работа доаѓ до согорување. Со цел да се намали професионалното согорување, вработените во рамки на фокус-групите имаа предлози работното време да се намали на 6 часа, да се зголеми бројот на техничкиот персонал кој ќе води сметка за хигиената, да се намали бројот на деца во секоја група и дополнително да се ангажираат стручни лица.

\section{Заклучок}

Податоците и предлозите изнесени од вработените во институциите кои работат со деца со умерена и тешка интелектуална попреченост, но и податоците изнесени во други истражувања укажуваат на исклучително тешки услови за работа. Ситуацијата со зголемување на деца со тешка интелектуална попреченост, на сметка на намалување на децата со умерена интелектуална попреченост кои се во сѐ поголем број во посебните училишта, како и на лица со комбинирани пречки и секундарни проблеми бара изедначување на условите под кои работат вработените во Специјалниот завод во Демир Капија. Ова значи дека треба сериозно да се размислува за разгледување и на можности за промени на законската легислатива за да се подобри квалитетот на животот на вработените. Постои потреба од дополнително мотивирање и стимулирање со воведување бенефициран работен стаж и функционален додаток, како и намалување на работното време на 6 часа. Дотогаш е потребно отворање нови дневни центри, континуирани обуки на вработените, надворешна мотивација и промени во менаџирањето на вонинституционалната заштита на деца со умерена и со тешка интелектуална попреченост. 


\section{Литератиура}

Mijalkov, B., Petrov, R, (2012), Tretment of persons with delays in intellectual development and consequences on helth of employees, Zlatibor

Rea Fulgosi Masnjak, Margareta Vidmar, Mia Masnjak, (2008), Sindrom pomagača kod djelatnika koji rade s osobama s oštećenjima vida, Hrvatska revija za rehabilitacijska istraživanja, Vol 44, br. 1, str. 27-38

Костиќ, И. В., Стојчевска, С. Б., Киткањ, В., Јовановиќ, Е., (2013), Проценка на професионалното согорување кај дефектолозите во Република Македонија вработени во различни институциии, Современи аспекти на специјалната едукација и рехабилитација, Охрид

Трајков, И., (2006), Професионалниот стрес кај социјални работници и психолози вработени во областа на социјалната заштита и здравството. Одбранет магистерски труд, Филозофски факултет Скопје, Институт за социјална работа и социјална политика

Трајковска, С. Н., (2015), Ефектите од вонинституционалната заштита на деца со умерена и тешка интелектуална попреченост во Република Македонија, Одбранета докторска дисертација, Филозофски факултет, Институт за дефектологија 


\section{REWARDED EMPLOYMENT STATUS AS NEED FOR EMPLOYEES IN NON- INSTITUTIONAL AND INSTITUTIONAL PROTECTION OF CHILDREN WITH MODERATE AND SEVERE INTELLECTUAL DISABILITY}

\section{Summary}

The system of protection and rehabilitation of persons with disability as well as the educational system in the Republic of Macedonia since year 2000 until today's date has gone thru various changes caused by processes of non-institutional care and inclusion. Such changes has caused significantly decreasing the number of children with moderate intellectual disability in day care centers and Institution for rehabilitation of children and youth "Topansko Pole" and due to this change on the other hand we have domination of children with severe intellectual disability.

Changing the structure of the beneficiaries, increasing the years of employment contract of the experts working with this children category and weak motivation is causing professional burn out.

The research is conducted on a sample of 16 experts employed in the Institution for rehabilitation of children and youth Topansko Pole from Skopje and 94 experts employed in day care centers throughout the Republic of Macedonia.

The experts hired for treatment of persons with severe intellectual disability in the Special Institution from Demir Kapija are with employment status for which is considered extended lasting, therefore the research is conducted with aim to observe if the experts covering this children category has needs of additional motivation and stimulation like implementing rewarded employment status as possibility for increasing the efficiency in working process and enhancing the quality of life of experts which are in direct and everyday contact with children with moderate and severe intellectual disability.

Keywords: CHILDREN WITH MODERATE AND SEVERE INTELLECTUAL DISABILITY, NON-INSTITUTIONAL AND INSTITUTIONAL PROTECTION, PROFESSIONAL BURN OUT, REWARDED EMPLOYMENT STATUS 